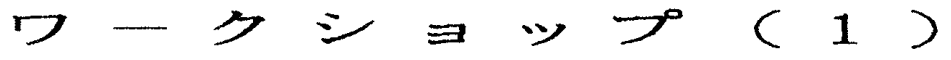

W1-2 薬物アレルギーの臨床皮虚科医の立場から

$$
\begin{aligned}
& \text { 早川律子 } \\
& \text { 名古屋大・分院・皮䖒科 }
\end{aligned}
$$

皮虚科診療の場で経験される薬物アレルギ一は莱疹と接触皮 展炎に大別される。

\title{
1. 薬疹
}

i. 発症機序

薬剂アレルギーの発症機序には不明の部分が多いが，(1) I gE 伝達性アレルギ一反応, (2) $\mathrm{T}$ 細胞伝達性アレルギ一反応とに大 きく分類できる。(1)にはIgE 抗体による脱顆粒反応, 補体の活 性化，自己抗体によるAＩ型反応なよ゙がある。(2)には T ${ }_{\mathrm{DH}}$ 細胞 によるdelayed hypersensitivity (D H ) と T c 細胞に誘導さ れるcytotoxicity（CT）型反応（GVHR型）がある。また , 薬剤アレルギーの誘導あるいは反応の過程で自己トレランス の破綻が生じ，それにより自己抗体の産生が誘導されて自己兔 疫型（A I）反応が生じる可能性もある（表 1）。

表 1. 莱剂アレルギーの発症機序

(1) IgE 伝達性アレルギー反応

i ） IgE 抗体による脱顆粒反応

ii）補体の活性化, immune complex型反応

iii）自己抗体によるAＩ型反応

(2) T細胞伝達性アレルギー反応

i ) $\mathrm{T}_{\mathrm{DH}}$ 細胞によるdelayed hypersensitivity ( D H ) 型反 応

ii） $\mathrm{T}_{\mathrm{c}}$ 細胞によるdytotoxicity（C T ）型反応 


\section{ii . 形態学的分類}

薬疹の表現形態は極めて多彩であり，既知の皮唐疾患に類似 の形態で発現することが多い。薬疹は原因薬郕が同一であって も，常に同じ病型を呈すると限らなく，病型から原因薬剤を確 定することは困難である。しかし発疹の形態からある程度の原 因薬片の推定は可能であり，検查や治療の方針を決定する上で ，薬疹の病型分類が役立つ。薬疹は以下の10型に分類される。

1) 蕈麻疹型

䓰麻疹型薬疹の原因薬剂としてはペニシリン, サルファ剂, ピリン類，インスリン，プロカイン，アスピリンなどがあげら れる。発症機序は, 薬剤（ハプテン）特異的 IgE 抗体を介した I 型アレルギーである。原因薬剂を用いたスクラッチ試験や皮 内試験で膨疹反応を呈する。しかし，血清中に薬剂特異的 $\mathrm{IgE}$ 抗体が就明されない場合もある。

2) 播種状紅斑丘疹型（多形紅斑型，紅皮症型）

沉発型薬疹で，真皮の血管拡張，血管周囲に細胞浸潤が認め られる。発症機序は D H 型反応によるといわれている。原因薬


，金製剤，チアジド系薬剂，抗生物質，P A S よ゙が報告され ている。

3) 湿疹型（紅色丘疹 - 漿液性丘疹型、全身性接触型皮府炎反 応）

瘦痒の強い漿液性丘疹を主体とする湿疹反応を呈し，組織学 的にはリンパ球の表皮内浸潤や表皮の海面状態を特徵とする。 発症機序はDHの一つの型である接触アレルギーと同じである と言わ㣗ている ${ }^{1}$ 。抗生物質，消炎鎮痛剂，抗七スタミン剂， 重金属，局所麻醉剂などで経皮感作された個体が同薬剂または 交差反応する薬剤の全身投与を受けると発症する。

4 ）多形淩出性紅斑型

主に四肢伸側に米粒大〜貨幣大までの浮腫性扁平紅斑，ある 
いは環状紅斑を生ずる型で，時に紅斑が療合して地図状となる 。疼痒は殆ど伴わない。原因薬剂として抗生物質, 感冒治療剂 , 造影剂, 消炎鎮痛剂, 化学療法剂, 経口避妊薬, 抗痤剂など が報告されている。組織学的には基底層およびその周辺の表皮 細胞の空砲变性, 好酸性壊死, 表皮内へのリンパ球浸潤なら゙が 見られ，発症機序は急性 GVHRの軽症型亡考えられている。

5 ）中毒性表皮壊死型（TEN 型）

表皮全層が壊死に陥る重症型の薬疹で, しばしば消炎鎮痛剂 , 抗生物質で発症する。突然疼痛を伴った紅斑が生じ，速やか に水疱が形成され表皮剝離が起こる。二コルスキ一現象が陽性 である。多形渗出性紅斑型の重症型と考えられている。

\section{6) 苔軅型}

従来は，発症までの期間が長いことや原因薬剂の投与中止に も係わらず皮疹の消退傾向がみられないことより非アレルギ一 による中毒説が主流であった。しかし組織学的に慢性 G V H D に見られると同様の表皮細胞の空砲变性, 好酸性壊死, sate1lite cellnecrosisなどの所見がみられ，慢性 G V H R と同様 の発症機序によるものとする考え方もある。シンナリジンによ る報告例が最も多いが，その他抗てんかん剂，消炎鎮痛剂，抗 神経剂, 脳代謝改善剂, 局所麻醉剂, 抗坑スタミン剂, 不整脈 治療剂, 利尿剂, 抗高血圧剂, 血管拡張剂, 呼吸促進剂, 抗甲 状腺剂, 糖尿病治療剂, 抗生物質, サルファ剂, 重金属などが 原因薬戍として報告されている。

\section{7 ) 固定疹型}

表皮基底層の障害によって生ずる貨幣状〜手掌大の境界鮮明 な紅斑で，紅斑消退後に色素沈着を残す。同一ないし類似の薬 剂の再投与により同一部位に再燃する。痹痒, 灼熱感, 熱感を 伴うことが多い。発症機序は慢性 G V H R 型あるいはantibody -dependent cell-mediated cyto-toxicity ?己考えられている 。サルファ㓲, パルビタール系薬剤, ピリン系薬剂, 抗生物質 
などにより発症する。

8 ）光線過敏型（光アレルギー性）

光のエネルギーにより形成された菓剂一自己蛋白結合物がア レルギー反応を誘発して発症する。降圧利尿剂, 消炎鎮痛剂, 抗神経剂, 経口糖尿病剂, 抗真菌剂, 抗癌剂, 血管拡張剂など で発症する。

\section{9 ) 紫斑型}

血管炎型と血小板減少型があり，血管炎型には組織学的に血 管壁のフィブリノイド変性と血管周囲の多核白血球浸潤, 核塵 の存在，血管壁へのIgや補体成分の沈着を認めるArthus型とこ れらの所見を伴わず赤血球の血管外漏出と血管周囲のリンパ球 浸潤を特徵とするD H 型がある。血小板減少型は血小板に結合 した薬剤への抗体を介する血小板破壊により生ずると考えられ ている。血管炎型は抗生物質, サルファ剂, フェニルブタゾン ，経口避妊剂などにより，血小板減少型は消炎鎮痛剤，金製剤 ，サルファ剂，キニーネ，抗生物質，抗結核剂などにより発症 する。

10）自己兔疫（天疮瘡, 類天疮瘡, S L E ) 型

薬剤と自己蛋白の結合が自己抗体の産生を誘導するとする説 と、素因十增悪作用とする両説がある。原因薬剂として降圧利 尿剂, フェノバルビタール，ヨード，ブロム， S H 製剤などが 報告されている。

2. 薬物経皮アレルギー

i. 発症機序

経皮吸収されたハプテンが表皮の細胞蛋白と結合して抗原性 を獲得し，感作リンパ球を誘導して接触アレルギーを発症する 。光のエネルギーが抗原性獲得に必要な場合を光アレルギー性 皮虜炎という。光アレルギーの発症機序ははっきりとは解明さ れていないが，1）物質が光のエネルギーによって変性し抗原性 を獲得する，2)物質と細胞蛋白と結合したものが光のエネルギ 
一によって抗原性を獲得する、3)光のエネルギーによって皮唐 の蛋白が变性して物質と結合しやすくなるなどの機序が考えら れている。

接触荽麻疹は物質の接触後 20 ３0分後に膨疹が生ずる現象を いい，発症機序は1）アレルギー反応、2)非アレルギ一反応，3） 機序不明に分類されている。

全身性接触型皮虚炎は経皮感作された個体に同一抗原あるい は交差反応をおこす物質が全身投与された場合に湿疹型薬疹の 形で発症する（表 2 ）。

表 2 . 経皮アレルギーの発症機序

(1)アレルギ一性接触皮虐炎（D H 型）

分子量1000以下のハプテンが表皮細胞蛋白と結合し抗原性を 獲得 $\rightarrow$ 感作リンパ球の誘導 $\rightarrow$ 接触アレルギーの発現

(2)光アレルギー性接触皮虛炎 (D H 型)

抗原性獾得に光のエネルギーが必要

(3)接触菷麻疹 (IgE 抗体伝達性)

物質の接触により膨疹を生ずる。

(4)全身性接触型皮厝炎 (D H 型)

経皮感作された個体に同一抗原あるいは交差反応をおこす物 質が全身投与されると湿疹型薬疹の形で発症する。

ii . 原因薬剂

1) コルチコステロイド2) 4)

従来コルチコステロイドによる経皮感作は稀であるといわれ ていたが, 報告例は決して少なくない。化学構造の類似したコ ルチコステロイド間の交差反応がみられる。

2) 非ステロイド5) 6)

接触アレルギ一，光接触アレルギーの報告がある。

3 ) 抗真菌剂 ${ }^{7}$ 
イミダゾール系抗真菌剂間の交差反応の報告が多い。

4 ) 抗生物質 ${ }^{7}$

ネオマイシンが最も多く報告されている。この他ゲンタマイ シン, リファマイシン, カナマイシン, クラムフェニコールな ビの報告がある。抗生物質間の交差反応も多い。

5 ）その他 ${ }^{7}$

抗ウイルス剂, 抗菌剂, 痤餈用剂, 抗癌剂, $\beta$ ブロッカー, 局所麻酔剂，止㾕剂，消毒剂，ヨードホルムなどによる接触皮 唐炎の報告がある。

6 ）外用剂基剂成分 ${ }^{7}$

ラノリン，プロピレングリコール，七チルアルコール，ステ アリールアルコール, ウイテップゾール, 防腐戍（ホルムアル デヒド，パラベン，クロロクレゾール，乳化剤, 安定剤, 抗 酸化剂，コロホニーなど外用剂基郕成分とし用いられる物質は 化粧品成分としても汎用されているものが多く，化精品皮鹿炎 患者の治療に際しては外用剂基剂成分に原因物質が含有されて いないことを確認する必要が有る。

7) 職業性経皮薬物アレルギー

塩酸ラニティディン（ザンタック）の製造過程の第 2 ステー ジでできる中間物質のジアミノ化合物（5-[(2-aminoethy 1$)$

thiomethyl ] N , N-dimethy1-2-furanmethanamine)による工 場従業員の職業性経皮感作例が報告されている ${ }^{81}$ 。

医師、茵科医, 獣医, 看護婦などで, 消毒剂, ホルムアルデ ヒド, プロカイン, ベンゾカイン, ペニシリン, ストレプトマ イシン，ホウ酸などの感作例が報告さている ${ }^{9)} 。$ 


\section{文献}

1. Fisher, A.A.: Systemic contact-type dermatitis, Fisher, A.A., Contact Dermatitis. 3rd. ed. Lea \& Febiger, Philadelphia, pp. 119-130, 1986.

2. Hayakawa, R.et al : Allergic contact dermatitis from amcinonide, Contact Dermatitis 12:213-214, 1985.

3. Hayakawa, R. et al : Allergic contact dermat it is from amcinonide, Contact Dermatitis $16: 48-49,1987$.

4. Hayakawa, $R$. et al: Allergic contact dermatitis due to amcinonide, Contact Dermatitis 23:49-50, 1990.

5. 松永佳世子他：Ibuprofen piconol によるアレルギ一性接触 皮唐炎の 4 例，皮唐，28增:168-176, 1986 。

6. 鈴木真理他：非ステロイド系抗炎症外用郕によるアレルギー 性接触皮唐炎, 皮唐, 29增:211-217, 1987.

7. 早川律子：経皮感作による莱物アレルギー 一最近の実態一 皮唐科M00K No.16 菜物之薬物アレルギ一 金原出版, 東 京, $\mathrm{pp} 242-253,1989$.

8. Rycroft, R. J.G.:Allergic contact dermatitis from a novel diamino intermediate, $5-(2$-aminoethy 1$)$ thiomethyl) $\mathrm{N}, \mathrm{N}$-dimethyl-2-furanmethanamine, in laboratory synthesis, Contact Dermatitis, $9: 456-458$, 1983.

9. 白田俊和他：手術用ゴム手袋および消毒剤による接触皮庸炎 ，皮病病敦 9:825-828，1987。 